\title{
A dynamic test of a vehicle in motion and exhaust gas emissions during alternative fuelling with gasoline and compressed natural gas (CNG)
}

\begin{abstract}
The majority of published data on exhaust gas emissions is cited based on the test results from the NEDC driving cycle. This paper specifies the methodology of how to develop dynamic characteristics of the emissions, based on the aggregated data from the measurement of modal emissions obtained in the course of NEDC and FTP-75 driving cycles for gasoline and CNG fuelling. The presented characteristics concern a real passenger car which was tested, then the characteristics were used to calculate the exhaust gas emissions during a specially developed driving test comprising four main motion resistances and engine braking. The effect of fuel type on selected emissions of exhaust gas components has also been compared and assessed.
\end{abstract}

Key words: car, ecology, exhaust gas emissions

\section{Test dynamiczny ruchu pojazdu a emisja składników spalin przy alternatywnym zasilaniu benzyną i gazem CNG}

\begin{abstract}
Większość publikowanych danych dotyczacych emisji skladników spalin jest podawana na podstawie badań w testach NEDC. W niniejszym artykule podano metodykę uzyskiwania charakterystyk dynamicznych emisji, opierając się na połączonych danych z pomiarów modalnych emisji uzyskanych w testach NEDC i FTP-75 dla zasilania benzyna $i$ gazem CNG. Przedstawiono takie charakterystyki dla konkretnego samochodu osobowego poddanego badaniom, a nastepnie wykorzystano te charakterystyki do obliczeń emisji sktadników spalin przy realizacji specjalnie opracowanego testu jezdnego, zawierającego cztery podstawowe opory ruchu i hamowanie silnikiem. Porównano i oceniono wpływ rodzaju paliwa na wybrane emisje składników spalin.
\end{abstract}

Słowa kluczowe: samochód, ekologia, emisja spalin

\section{Introduction}

A growing development of automotive industry in Poland after the political transformation in 1989 generates a necessity of development of the existing road network and its adaptation to a function which integrates individual regions and states. The majority of local governments have met these needs through development the modernization and extension plans of the road network in their area. In this task the existing topographical and social conditions as well as economic circumstances were taken into account. The conditions of sustainable development also require an assessment of an impact of the planned investments on the natural environment. In the case of the anticipated ecological menace, these plans should undergo corrections or be analyzed once again. The assessment of gaseous emissions from the automotive industry can serve as an ancillary and indispensable material for the analysis of the planned layout of the extension of the road network. The important factors impacting such analysis are:

- anticipated minimum and maximum traffic volume,

- the characteristics of the composition of the exhaust gas components, emitted by a statistic fleet of vehicles in an analyzed region,

- anticipated scenarios of traffic for various seasons, resulted from terrain configuration, planned crossroads and speed limits.

\section{Wprowadzenie}

Rozwój motoryzacji w Polsce po przemianach ustrojowych roku 1989 wywołuje konieczność rozbudowy istniejącej sieci dróg i dostosowanie ich do pełnienia funkcji czynnika integrującego regiony i państwa. Większość samorządów lokalnych wyszła naprzeciw tym potrzebom, opracowując plany modernizacji i rozbudowy sieci drogowych na własnych terenach. Kierowano się przy tym istniejącymi uwarunkowaniami topograficznymi, społecznymi i przesłankami ekonomicznymi. Warunki zrównoważonego rozwoju wymagają również oceny wpływu planowanych inwestycji na środowisko naturalne. W przypadku przewidywania zagrożeń ekologicznych plany te powinny być poddane korekcie lub ponownie przeanalizowane. Materiałem pomocniczym a zarazem niezbędnym do prowadzenia kompleksowych analiz rozbudowy sieci drogowej mogą być oceny emisji gazów pochodzenia motoryzacyjnego dla planowanych przebiegów dróg. Istotnymi czynnikami wpływającymi na tę analizę są:

- przewidywane minimalne i maksymalne natężenia ruchu,

- charakterystyka emisji składników spalin przez statystyczną flotę pojazdów rozpatrywanego regionu,

- przewidywane scenariusze ruchu dla różnych pór roku, wynikające $\mathrm{z}$ ukształtowania terenu, planowanych skrzyżowań i ograniczeń prędkości. 
The knowledge of the above mentioned factors enables quantitative and qualitative assessment of the source of emissions from the automotive sector and to anticipate the future effects.

The paper illustrates the possibilities of application of the dynamic characteristics in valuation of the fuel consumption and exhaust gas emissions for alternative fuelling with gasoline and $\mathrm{CNG}$ in the exemplary driving test. The test comprises four main traction resistances, i.e. rolling resistance, climbing resistance, drag resistance and inertia resistance, which were transferred into the dynamic characteristics in the form of 'substitute acceleration', described in the function of speed. The above mentioned substitute acceleration was calculated from the equation of vehicle motion based on the motion parameters prescribed during the test. The proposed test also comprises a phase of engine braking.

\section{Construction of the dynamic characteristics}

The dynamic characteristics, describing exhaust emissions and fuel consumption in the function of driving speed and vehicle linear acceleration or angular velocity and crankshaft angular acceleration, constitute the basis for further analyses. The methodologies of development of such characteristics based on the modal measurements of exhaust gas emissions in NEDC and FTP-75 driving cycle tests have been described in works [1, 2, 3]. For the needs of the present work the authors assumed that only the dynamic characteristics based on the above mentioned tests, in the operating range with a fully heated catalytic converter, shall be taken into consideration. The ranges of the driving tests constituting the source of the data to approximate the calculations have been shown in Fig. 1 and 2. The implementation of such ranges resulted from the data contained in [4] and [5].

The dynamic characteristics were elaborated with the assumption, that there exists a possibility of their representation with a sufficient accuracy using surfaces described by polynomials of the third order [6]. In the successive Fig. 3
Znajomość wymienionych czynników pozwoli na ocenę jakościową i ilościową źródeł emisji gazów pochodzenia motoryzacyjnego i przewidywanie skutków tego stanu.

W niniejszym artykule przedstawiono możliwości aplikacji charakterystyk dynamicznych do oceny zużycia paliwa i emisji składników spalin dla alternatywnego zasilania benzyną i gazem CNG w przykładowym teście jezdnym. W teście występują cztery podstawowe opory ruchu: toczenia, wzniesienia, powietrza i bezwładności, które przeniesiono na charakterystyki dynamiczne w postaci tzw. przyspieszenia zastępczego, ujętego w funkcji prędkości. Wspomniane przyspieszenie zastępcze obliczano z równania ruchu samochodu wyposażonego w silnik o znanej charakterystyce. W dalszej części publikacji opisano równanie ruchu ujmujące opory: toczenia, powietrza, wzniesienia, bezwładności i hamowania silnikiem.

\section{Budowa charakterystyk dynamicznych}

Podstawą dalszych analiz przedstawionych w niniejszej publikacji są tzw. charakterystyki dynamiczne, ujmujące emisję składników spalin i zużycie paliwa jako funkcję prędkości jazdy i przyspieszenia liniowego pojazdu lub jako funkcję prędkości kątowej i przyspieszenia kątowego wału korbowego silnika. W publikacjach [1, 2, 3] opisano metodyki tworzenia takich charakterystyk, opierając się na pomiarach modalnych emisji składników spalin w testach jezdnych NEDC i FTP-75. Na potrzeby niniejszej publikacji przyjęto, że będą rozpatrywane charakterystyki dynamiczne opracowane na bazie wspomnianych testów w zakresie pracy z w pełni nagrzanym reaktorem katalitycznym. Na rysunkach 1 i 2 przedstawiono zakresy testów jezdnych, $z$ których dane przyjęto do obliczeń aproksymacyjnych. Przyjęcie takich zakresów wynikało z danych zawartych w $[4,5]$.

Charakterystyki dynamiczne emisji opracowano, przyjmując, że można je z wystarczającą dokładnością odwzorować powierzchniami opisanymi wielomianami trzeciego stopnia [6]. Na rysunkach 3 i 4 przedstawiono wybrane charakterystyki dynamiczne zużycia paliwa opracowane na

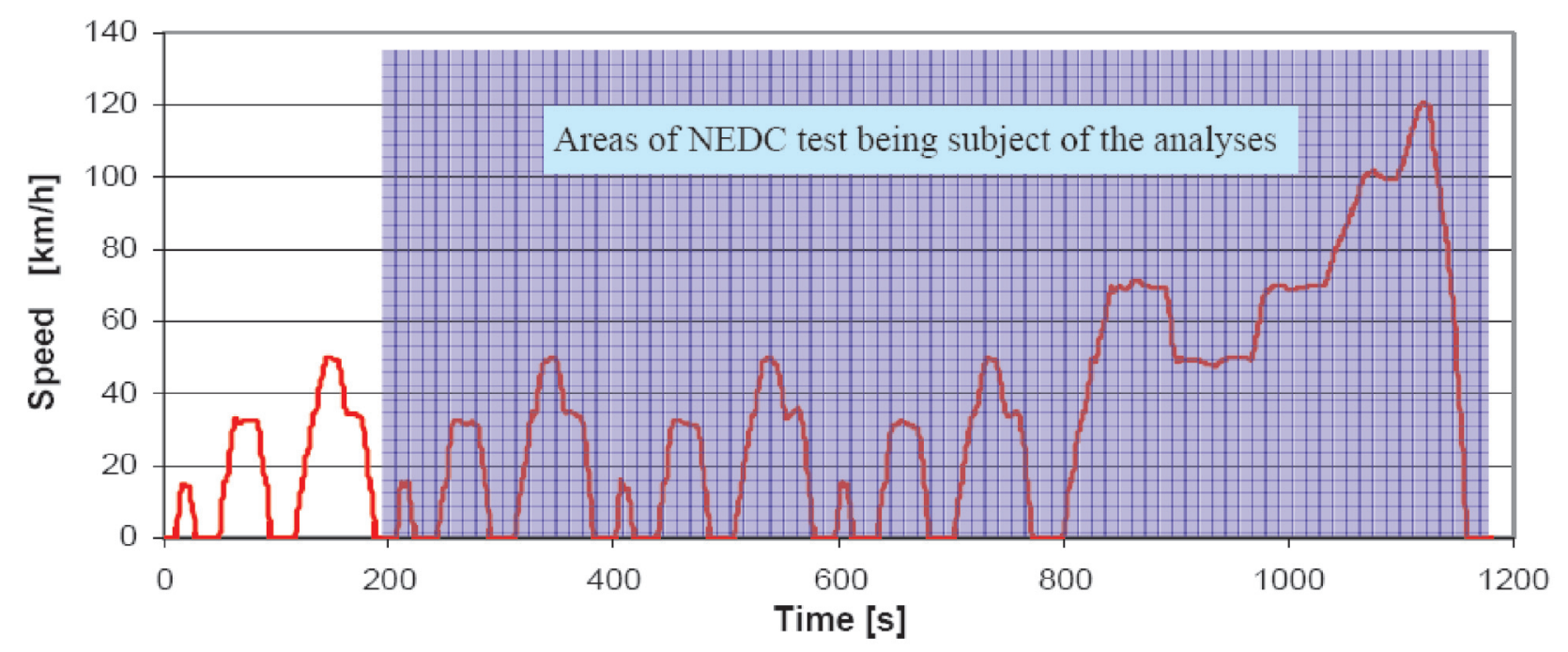

Fig. 1. NEDC driving cycle with marked ranges which were subjected to the analysis

Rys. 1. Test jezdny NEDC z zaznaczonymi zakresami, które były przedmiotem analiz 


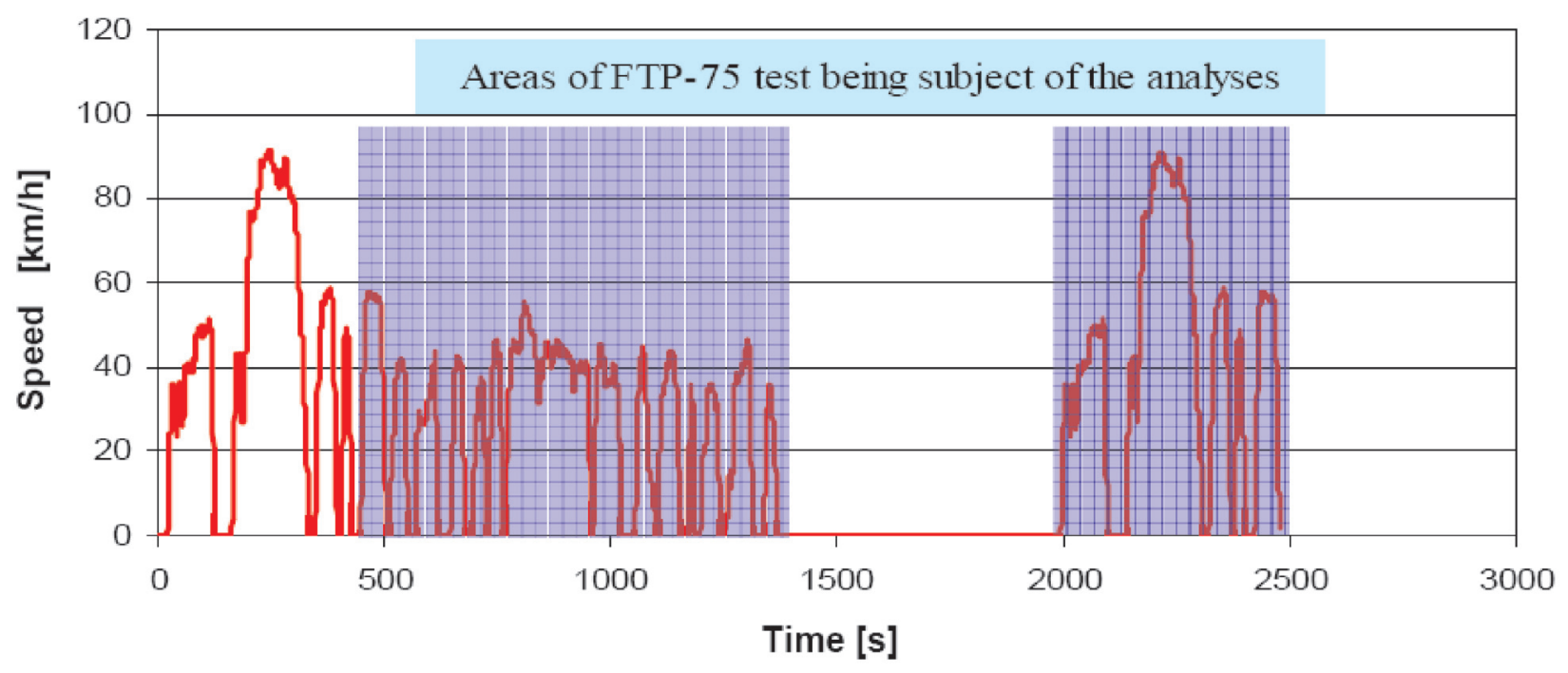

Fig. 2. FTP-75 driving cycle with marked ranges which were subjected to the analysis

Rys. 2. Test jezdny FTP-75 z zaznaczonymi zakresami, które byty przedmiotem analiz

and 4 selected dynamic characteristics of fuel consumption have been shown, elaborated based on the carbon balance for segment $\mathrm{C}$ passenger car, powered alternatively by gasoline in MPI (Multi Point Injection) system and CNG in multipoint sequence injection by a factory-made system. The presented characteristics have been developed by approximating the data from the modal measurements with $1 \mathrm{~s}$ interval. The tests were performed in a certified toxic emissions laboratory OBR BOSMAL in Bielsko-Biała. The presented dynamic characteristics do not show the areas of the use of the vehicle in motion as they are based on the approximations in the assumed ranges of variability of speed and accelerations. [1] has been devoted to the limitations as to the use of the characteristics. We can assume that these limitations are determined by the characteristics of the vehicle dynamic index [9].

Map of gasoline consumption/ Charakterystyka zużycia benzyny

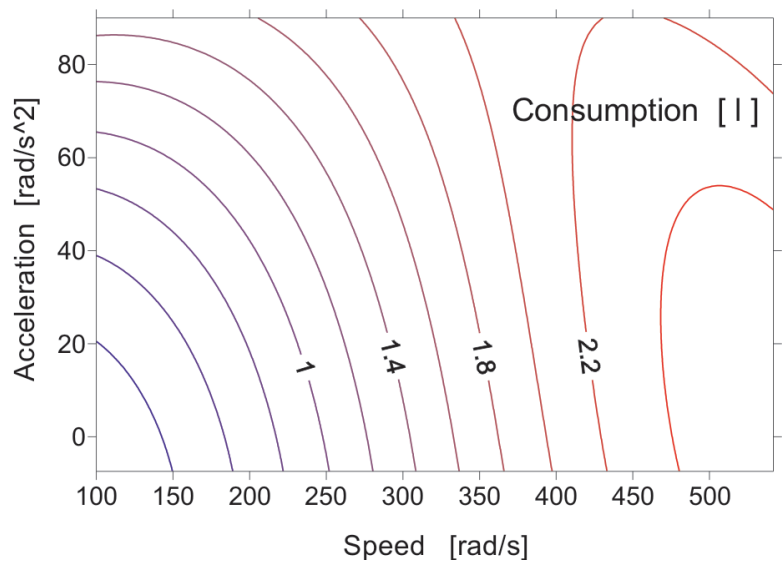

podstawie bilansu węgla dla samochodu osobowego klasy handlowej $\mathrm{C}$ zasilanego alternatywnie z jednej z instalacji: benzyną w systemie MPI (Multi Point Injection) lub gazem CNG w systemie sekwencyjnego wtrysku wielopunktowego, zabudowanego fabrycznie. Przedstawione charakterystyki opracowano, aproksymując dane z pomiarów modalnych z krokiem $1 \mathrm{~s}$. Badania przeprowadzono w certyfikowanym laboratorium toksyczności spalin OBR BOSMAL w Bielsku-Białej. Przedstawione charakterystyki dynamiczne nie uwidaczniają obszarów wykorzystania w ruchu samochodu, gdyż jak zaznaczono, są oparte na aproksymacjach w założonych zakresach zmienności prędkości i przyspieszeń. Ograniczeniom wykorzystania charakterystyk poświęcono publikację [1]. Można przyjąć, że w przybliżeniu ograniczenia te określa charakterystyka wskaźnika dynamicznego samochodu [9].

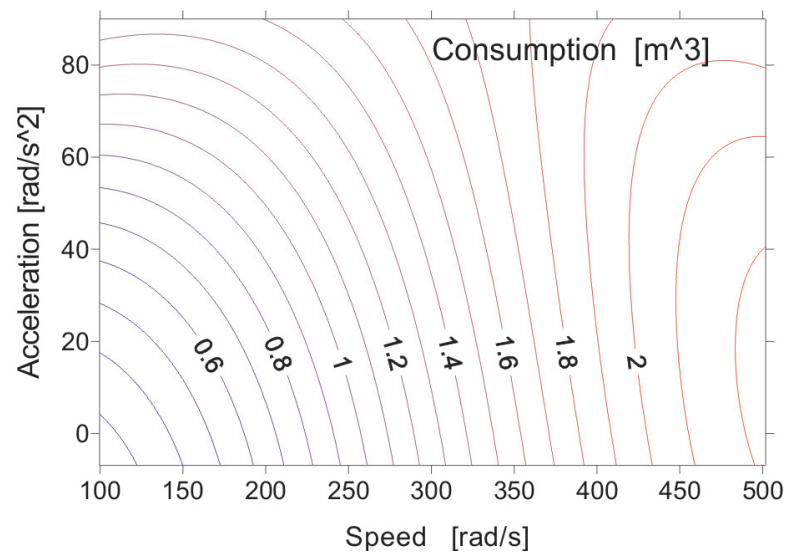

Fig. 3. Dynamic characteristics of gasoline and CNG fuelling of the car under consideration Rys. 3. Charakterystyka dynamiczna zużycia benzyny i CNG dla samochodu przyjętego do badań 


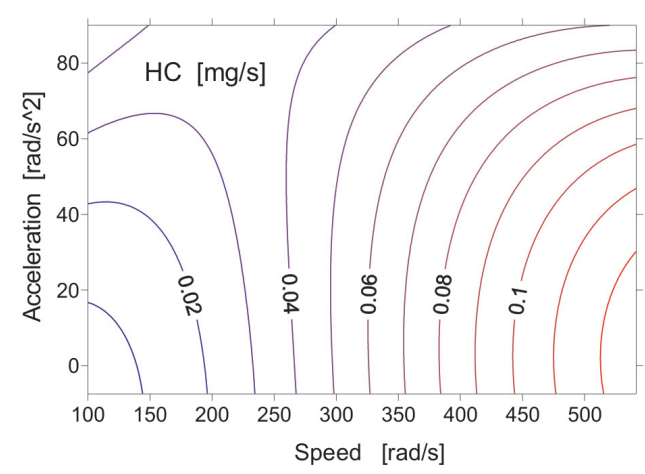

Map of $\mathrm{HC}$ emissions for gasoline fuelling/ Charakterystyka emisji HC dla zasilania benzyna

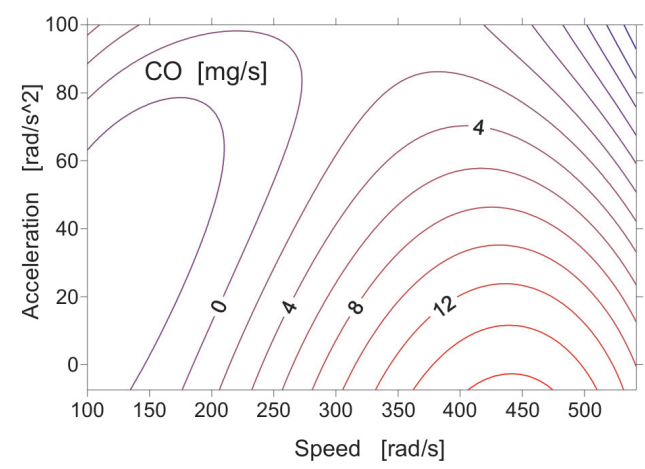

Map of $\mathrm{CO}$ emissions for gasoline fuelling/ Charakterystyka emisji CO dla zasilania benzyna

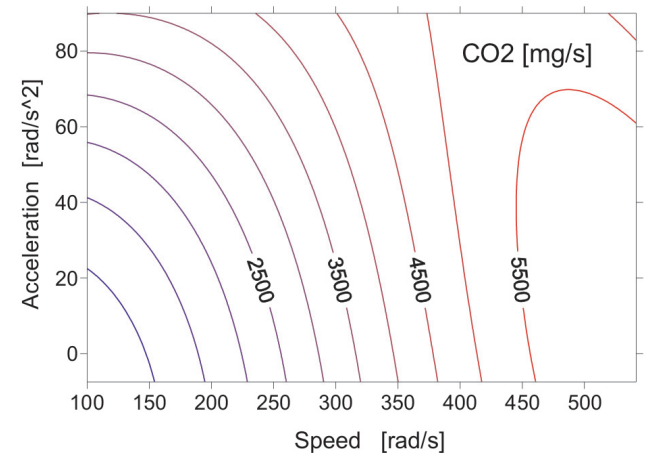

Map of $\mathrm{CO}_{2}$ emissions for gasoline fuelling/ Charakterystyka emisji $\mathrm{CO}_{2}$ dla zasilania benzyna

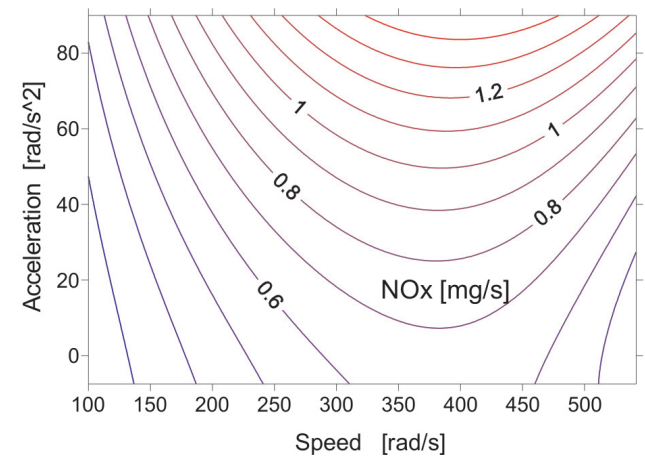

Map of $\mathrm{NO}_{x}$ emissions for gasoline fuelling/ Charakterystyka emisji $N O_{x}$ dla zasilania benzyna

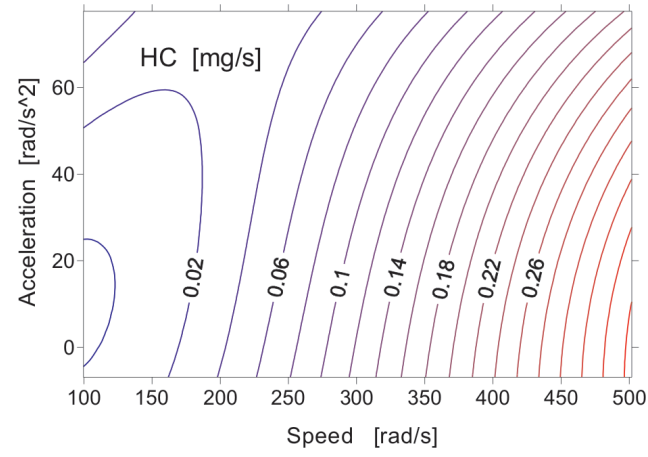

Map of $\mathrm{HC}$ emissions for CNG fuelling/ Charakterystyka emisji HC dla zasilania CNG

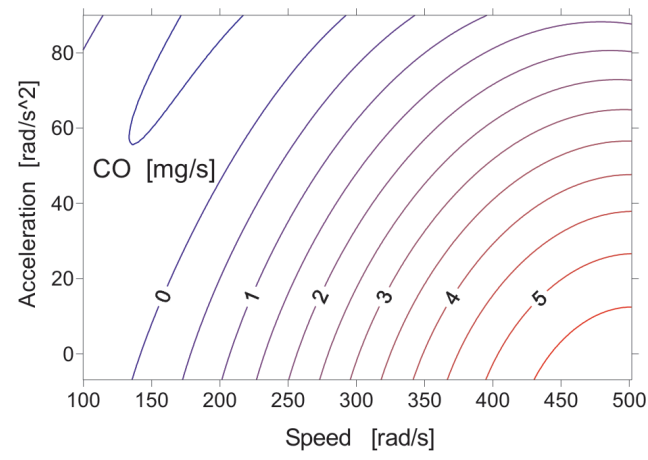

Map of CO emissions for CNG fuelling/ Charakterystyka emisji CO dla zasilania CNG

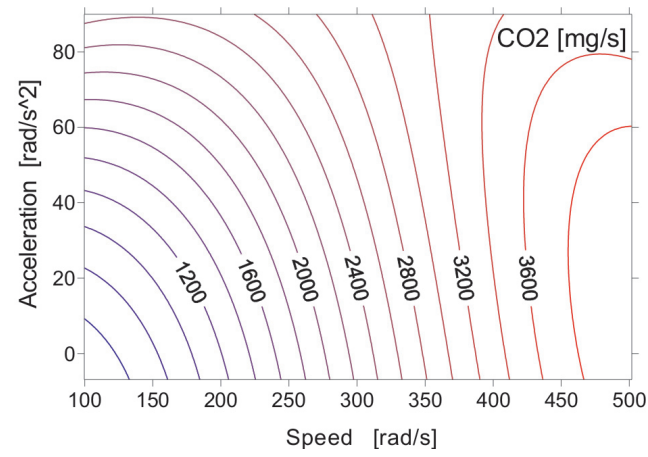

Map of $\mathrm{CO}_{2}$ emissions for $\mathrm{CNG}$ fuelling/ Charakterystyka emisji $\mathrm{CO}_{2}$ dla zasilania $\mathrm{CNG}$

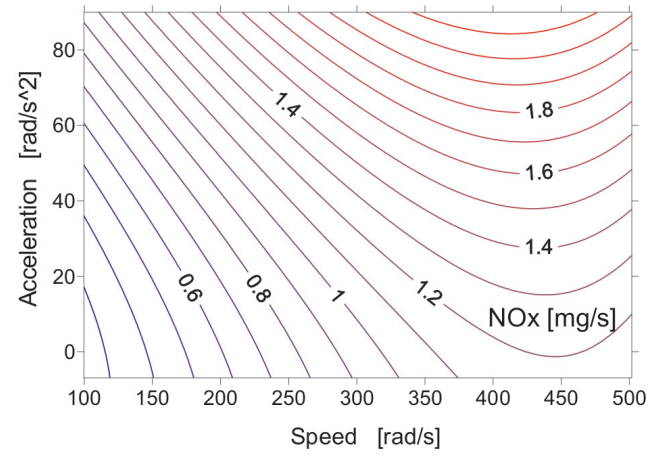

Map of $\mathrm{NO}_{\text {e }}$ emissions for CNG fuelling/ Charakterystyka emisji $N O_{x}$ dla zasilania $C N G$

Fig. 4. Dynamic characteristics of the exhaust gas components for the analyzed car, powered by gasoline and CNG Rys. 4. Charakterystyki dynamiczne emisji składników spalin dla zasilania benzyną i CNG dla samochodu przyjętego do badań 
Making qualitative and quantitative assessment of these characteristics it should be remembered that these characteristics were developed for the analyzed car, for the predetermined conditions of motion specific for driving cycles under investigation and they can be different in case of a different spectrum of engine loads. The authors of the paper, however, assume that these characteristics are representative to the same extent as the specified fuel consumption in UDC, EUDC and NEDC driving cycles. Comparing the dynamic characteristics for gasoline and CNG fuelling, we can simply assess the influence of the type of fuel on the emissions by the values and courses of the isolines. The similarities of the local extremes and the gradients of changes are worth mentioning here. The occurrence of the local negative emission values results from the assumed methodology of approximation. These values do not fall into the possible fields of operation of a vehicle.

\section{Testing driving cycle and equation of vehicle motion}

One can directly take advantage of the developed characteristics during the analysis of the vehicle motion in the function of velocity and angular acceleration of engine crankshaft. Moreover, the obtained characteristics can also be utilized to analyze the vehicle motion when all four main motion resistances are present i.e. rolling resistance, climbing resistance, drag resistance and inertia resistance. In such a case, making use of the equation of motion one can calculate the 'substitute acceleration', which enables a representation of motion resistances on the obtained dynamic characteristics. The equation of motion in the following form was applied:

$$
\begin{gathered}
F_{n}=F_{t}+F_{w}+F_{p}+F_{b} \\
F_{n}=m \cdot g \cdot(f \cdot \cos \alpha+\sin \alpha)+ \\
+0,646 \cdot C_{x} \cdot A \cdot V^{2}+ \\
+m \cdot\left(1+\frac{I_{s} \cdot i_{c b}^{2} \cdot \eta_{m}}{m \cdot r_{d}^{2}}+\frac{4 \cdot I_{k}}{m \cdot r_{d}^{2}}\right) \cdot \frac{d V}{d t} \\
F_{n}=\frac{M_{s} \cdot i_{b} \cdot i_{g} \cdot \eta_{m}}{r_{d}} \\
V=\frac{\omega \cdot r_{d}}{i_{b} \cdot i_{g}} \\
\frac{d V}{d t}=\frac{d \omega}{d t} \cdot \frac{r_{d}}{i_{b} \cdot i_{g}}
\end{gathered}
$$

where: $\mathrm{M}_{\mathrm{s}}$ - engine's moment of inertia $[\mathrm{N} \cdot \mathrm{m}], \mathrm{F}_{\mathrm{n}}$ - motive force $[\mathrm{N}], \mathrm{F}_{\mathrm{t}}$ - rolling resistance force $[\mathrm{N}], \mathrm{F}_{\mathrm{w}}$ - climbing resistance force $[\mathrm{N}], \mathrm{F}_{\mathrm{p}}-$ drag resistance force $[\mathrm{N}], \mathrm{F}_{\mathrm{b}}-$ inertia resistance force $[\mathrm{N}], \mathrm{m}=1750 \mathrm{~kg}$ - total mass of vehicle, $g=9.81 \mathrm{~m} / \mathrm{s}^{2}-$ gravitation acceleration, $\mathrm{f}=0.012$ - rolling resistance coefficient, $\mathrm{C}_{\mathrm{x}}=0.39$ - drag resistance coefficient, $\mathrm{A}=2.468 \mathrm{~m}^{2}$ - maximum vehicle cross section, $r_{d}=0.293 \mathrm{~m}-$ dynamic radius of tyres, $I_{s}=0.0481 \mathrm{~kg} \cdot \mathrm{m}^{2}$ - mass moment of inertia of engine moving components,
Oceniając jakościowo i ilościowo te charakterystyki, należy pamiętać, iż powstały one dla badanego samochodu, określonych warunków ruchu ujętych testami jezdnymi i mogą się różnić dla innego widma obciążeń silnika. Autorzy publikacji przyjmują jednak, iż są one reprezentatywne $\mathrm{w}$ takim samym stopniu, jak podawane zużycia paliwa $\mathrm{w}$ cyklach jezdnych UDC, EUDC i NEDC.

Porównując charakterystyki dynamiczne dla zasilania benzyną i gazem CNG, można już na podstawie wartości i przebiegu izolinii ocenić wpływ rodzaju paliwa na emisję składników spalin. Warto zwrócić uwagę na podobieństwa co do położenia lokalnych ekstremów jak i gradienty zmian. Występowanie lokalnych ujemnych wartości emisji wynika z przyjętej metodyki aproksymacji. Wartości te nie leżą w możliwych polach eksploatacji samochodu.

\section{Testowy cykl jezdny i równanie ruchu}

Analizując ruch samochodu jako funkcję prędkości i przyspieszenia kątowego wału korbowego silnika, można bezpośrednio korzystać z opracowanych charakterystyk. Również można wykorzystać uzyskane charakterystyki do analiz ruchu, w którym występują wszystkie cztery podstawowe opory ruchu, a więc; toczenia, wzniesienia, powietrza i bezwładności. W takim przypadku, korzystając z równania ruchu, można obliczyć tzw. przyspieszenie zastępcze, pozwalające na odwzorowanie oporów ruchu na uzyskanych charakterystykach dynamicznych. Do obliczeń przyjmowano równania ruchu (1) - (5),

gdzie: $\mathrm{M}_{\mathrm{s}}$ - moment obrotowy silnika $[\mathrm{N} \cdot \mathrm{m}], \mathrm{F}_{\mathrm{n}}$ - siła napędowa $[\mathrm{N}], \mathrm{F}_{\mathrm{t}}$ - siła oporu toczenia $[\mathrm{N}], \mathrm{F}_{\mathrm{w}}-$ siła oporu wzniesienia $[\mathrm{N}], \mathrm{F}_{\mathrm{p}}-$ siła oporu powietrza $[\mathrm{N}], \mathrm{F}_{\mathrm{b}}-$ siła oporu bezwładności $[\mathrm{N}], \mathrm{m}=1750 \mathrm{~kg}-$ masa całkowita pojazdu, $\mathrm{g}=9,81 \mathrm{~m} / \mathrm{s}^{2}-$ przyspieszenie ziemskie, $\mathrm{f}=0,012$ - współczynnik oporu toczenia, $\mathrm{C}_{\mathrm{x}}=0,39$ - współczynnik oporu powietrza, $\mathrm{A}=2,468 \mathrm{~m}^{2}-$ powierzchnia czołowa, $r_{d}=0,293 \mathrm{~m}-$ promień dynamiczny koła, $I_{\mathrm{s}}=0,0481 \mathrm{~kg} \cdot \mathrm{m}^{2}$ - masowy moment bezwładności elementów ruchomych silnika zredukowany do osi wału korbowego, $\mathrm{I}_{\mathrm{k}}=0,4424 \mathrm{~kg} \cdot \mathrm{m}^{2}$ - masowy moment bezwładności koła, $\alpha$ - kąt wzniesienia, $\eta_{\mathrm{m}}$ - sprawność układu przeniesienia napędu na poszczególnych biegach, $\mathrm{i}_{\mathrm{cb}}=\mathrm{i}_{\mathrm{g}} \cdot \mathrm{i}_{\mathrm{b}}$ - przełożenie całkowite na danym biegu $\left(\mathrm{i}_{\mathrm{c} 1}=15,116 ; \mathrm{i}_{\mathrm{c} 2}=8,345 ; \mathrm{i}_{\mathrm{c} 3}=5,723 ; \mathrm{i}_{\mathrm{c} 4}=4,335 ; \mathrm{i}_{\mathrm{c} 5}=\right.$ $3,562), \mathrm{V}$ - prędkość pojazdu [m/s], dV/dt - przyspieszenie pojazdu $\left[\mathrm{m} / \mathrm{s}^{2}\right], \omega_{\mathrm{s}}-$ prędkość kątowa silnika $[\mathrm{rad} / \mathrm{s}]$.

Dla samochodu toczącego się bez hamowania (hamowanie silnikiem) przyjęto równania (6) i (7),

gdzie: $\delta_{\mathrm{s}}=\frac{\mathrm{I}_{\mathrm{s}} \cdot \mathrm{i}_{\mathrm{cb}}^{2} \cdot \eta_{\mathrm{m}}}{\mathrm{m} \cdot \mathrm{r}_{\mathrm{d}}{ }^{2}} ; \delta_{\mathrm{k}}=\frac{4 \cdot \mathrm{I}_{\mathrm{k}}}{\mathrm{m} \cdot \mathrm{r}_{\mathrm{d}}{ }^{2}}$

lub według [7] równanie (8),

gdzie: $\mathrm{F}_{\text {na }}=\mathrm{A}+0,3 \cdot \mathrm{V}$ - siła oporu mechanizmów układu napędowego, $\mathrm{W}=10$ (dla samochodów $\mathrm{z}$ napędem przednim i silnikiem ułożonym poprzecznie z przodu), V - zmienna prędkość ruchu $[\mathrm{m} / \mathrm{s}], \mathrm{F}_{\mathrm{s}}=\mathrm{q} \cdot \mathrm{n}_{\mathrm{s}}+\mathrm{B}-$ siła oporu silnika $[\mathrm{N}]$, $\mathrm{q}=\frac{\mathrm{V}_{\mathrm{s}}}{0,2 \cdot \mathrm{P}}$, gdzie: $\left(\mathrm{V}_{\mathrm{s}}-\right.$ objętość skokowa silnika $\mathrm{w}\left[\mathrm{dm}^{3}\right]$, 
reduced to crankshaft axis, $I_{k}=0.4424 \mathrm{~kg} \cdot \mathrm{m}^{2}-$ mass moment of inertia of a wheel, $\alpha$ - climbing angle, $\eta_{\mathrm{m}}$ - efficiency of the transmission system, $\mathrm{i}_{\mathrm{cb}}=\mathrm{i}_{\mathrm{g}} \cdot \mathrm{i}_{\mathrm{b}}$ - total ratio on a given gear, $\mathrm{V}$ - vehicle speed $[\mathrm{m} / \mathrm{s}], \mathrm{dV} / \mathrm{dt}$ - vehicle acceleration $\left[\mathrm{m} / \mathrm{s}^{2}\right], \omega_{\mathrm{s}}$ - engine angular velocity $[\mathrm{rad} / \mathrm{s}]$.

For the car running without regular braking (braking with the engine):

$$
\mathrm{Fn}=0
$$

$$
\begin{aligned}
& \ddot{x}=\frac{m \cdot g \cdot(f \cdot \cos \alpha+\sin \alpha)}{m \cdot\left(1+\delta_{s}+\delta_{k}\right)}+ \\
& +\frac{0,646 \cdot C_{x} \cdot A \cdot V^{2}}{m \cdot\left(1+\delta_{s}+\delta_{k}\right)}
\end{aligned}
$$

where: $\delta_{\mathrm{s}}=\frac{\mathrm{I}_{\mathrm{s}} \cdot \mathrm{i}_{\mathrm{cb}}^{2} \cdot \eta_{\mathrm{m}}}{\mathrm{m} \cdot \mathrm{r}_{\mathrm{d}}^{2}} ; \delta_{\mathrm{k}}=\frac{4 \cdot \mathrm{I}_{\mathrm{k}}}{\mathrm{m} \cdot \mathrm{r}_{\mathrm{d}}^{2}}$

or acc. to [7]:

$$
\begin{aligned}
& \ddot{x}=\frac{\mathrm{m} \cdot \mathrm{g} \cdot(\mathrm{f} \cdot \cos \alpha+\sin \alpha)}{\mathrm{m} \cdot\left(1+\delta_{\mathrm{s}}+\delta_{\mathrm{k}}\right)}+ \\
& +\frac{0,646 \cdot \mathrm{C}_{\mathrm{x}} \cdot \mathrm{A} \cdot \mathrm{V}^{2}+\mathrm{F}_{\mathrm{na}}+\mathrm{F}}{\mathrm{m} \cdot\left(1+\delta_{\mathrm{s}}+\delta_{\mathrm{k}}\right)}
\end{aligned}
$$

where: $F_{n a}=A+0,3 \cdot V-$ motion resistance force of the powertrain mechanisms, $\mathrm{W}=10$ (for cars with front wheel drive and transverse engine configuration in the front), $\mathrm{V}$ - variable speed of motion $(\mathrm{m} / \mathrm{s}), \mathrm{F}_{\mathrm{s}}=\mathrm{q} \cdot \mathrm{n}_{\mathrm{s}}+\mathrm{B}$ - engine resistance force $[\mathrm{N}], \mathrm{q}=\frac{\mathrm{V}_{\mathrm{s}}}{0,2 \cdot \mathrm{P}} ; \mathrm{V}_{\mathrm{s}}$ - engine swept volume in $\left[\mathrm{dm}^{3}\right], \mathrm{P}$ - engine power $[\mathrm{kW}], \mathrm{n}_{\mathrm{s}}=\frac{\mathrm{V} \cdot \mathrm{i}_{\mathrm{b}} \cdot \mathrm{i}_{\mathrm{g}}}{2 \cdot \pi \cdot \mathrm{r}_{\mathrm{d}}}-$ engine speed $[\mathrm{rpm}], \mathrm{B}=10 \cdot \sqrt{\mathrm{V}_{\mathrm{s}}}$

The equations specified above were used to calculate the 'substitute accelerations' for the assumed, comparative dynamic driving test, the run of which is shown in Table 1 and in Fig. 5. The adaptation of the assumed motion parameters to engine performance was needed during the development of the test. In the considered case, the lower engine output power was generated by the engine fuelled with CNG (Fig. 6) and this very fact determined the run of the test. Hence, the data specified in Table 1 concern CNG fuelling; for
$\mathrm{P}-$ moc silnika $[\mathrm{kW}]), \mathrm{n}_{\mathrm{s}}=\frac{\mathrm{V} \cdot \mathrm{i}_{\mathrm{b}} \cdot \mathrm{i}_{\mathrm{g}}}{2 \cdot \pi \cdot \mathrm{r}_{\mathrm{d}}}-$ prędkość obrotowa silnika $[\mathrm{obr} / \mathrm{s}], \mathrm{B}=10 \cdot \sqrt{\mathrm{V}_{\mathrm{s}}}$.

Powyższe równania użyto do obliczeń ,przyspieszeń zastępczych" dla założonego porównawczego, dynamicznego testu jezdnego, którego przebieg ujęto w tab. 1 i na rys. 5. Przy konstrukcji testu konieczne jest dostosowanie założonych parametrów ruchu do osiągów silnika. W rozpatrywanym przypadku mniejsze moce osiągał silnik zasilany gazem CNG (rys. 6) i właśnie ten fakt determinował przebieg testu. Stąd też dane zawarte w tab. 1 dotyczą zasilania gazem $\mathrm{CNG}$, a dla zasilania benzyną wynikają z założenia, że w każdej fazie testu I - VI samochód przejeżdża tę samą drogę przy zasilaniu benzyną i gazem CNG. W ruchu na biegu I wykorzystywano 50\% momentu maksymalnego charakterystyki szybkościowej silnika, a na biegach II i III wykorzystywano maksymalne momenty ujęte charakterystykami szybkościowymi dla zasilania benzyną i gazem CNG. Takich założenia skutkowały tym, że przyjęty zakres zmienności prędkości obrotowych dla zasilania CNG jest innym zakresem zmian prędkości obrotowych niż przy zasilaniu benzyną.

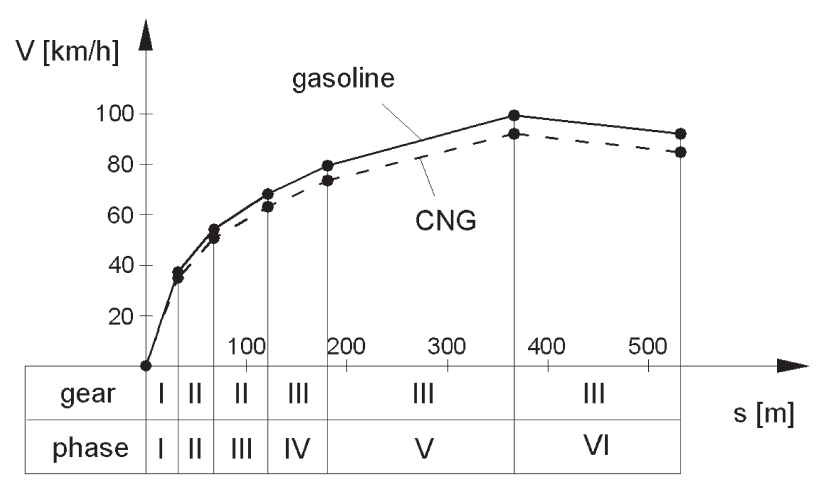

Fig. 5. Course of the test Rys. 5. Przebieg testu

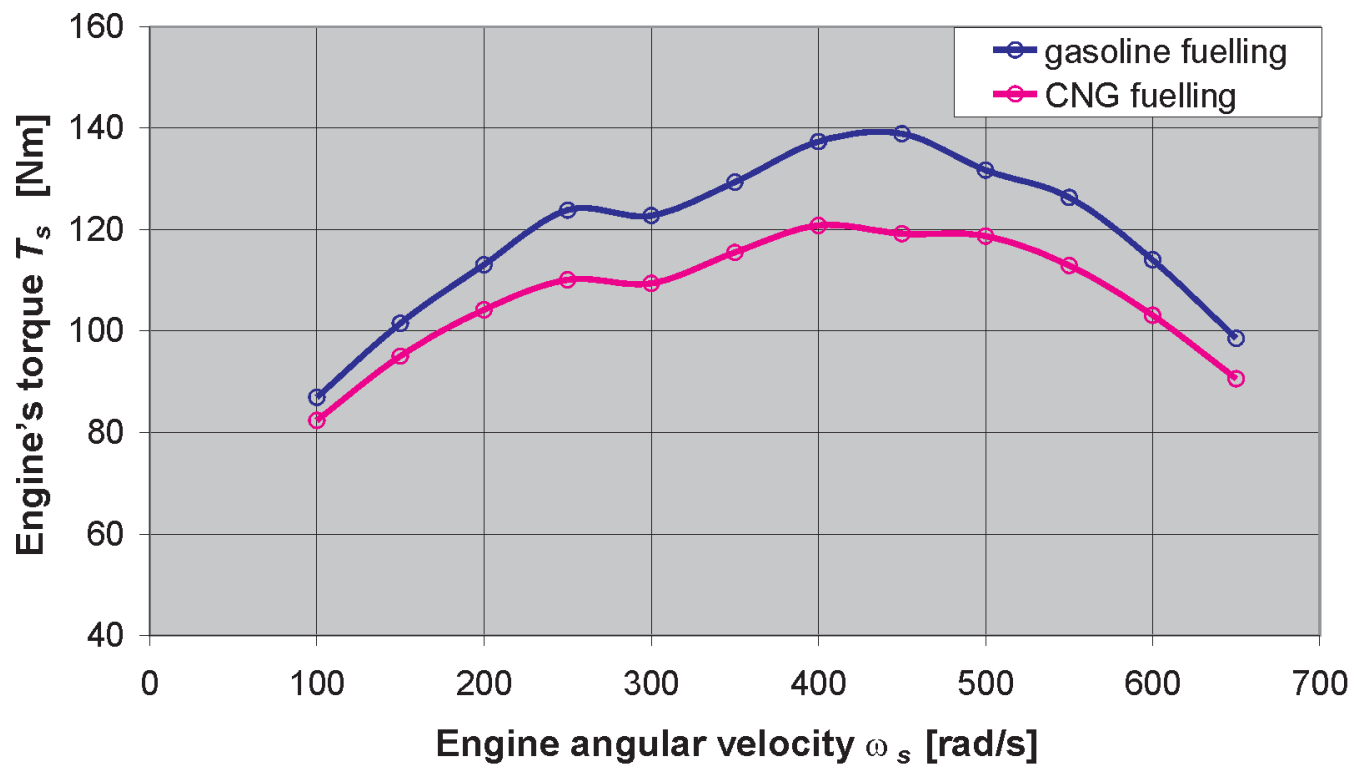

Fig. 6. Engine torque curves of the tested car for gasoline and CNG fuelling

Rys. 6. Charakterystyki szybkościowe silnika badanego samochodu przy zasilaniu benzyna i CNG 
gasoline fuelling the data result from the assumption that in any phase of the test (I-VI) the car covers the same distance powered by both gasoline and $\mathrm{CNG}$. In the motion in the $1^{\text {st }}$ gear $50 \%$ maximum torque from engine torque curves was utilized, whereas in the $2^{\text {nd }}$ and $3^{\text {rd }}$ gears maximum torques formulated by torque curves for gasoline and CNG fuelling were utilized. Taking such assumptions resulted in that the assumed variability of the engine speed range for CNG fuelling was different than in the case of gasoline fuelling.

\section{Obtained results}

Evaluating the obtained results one should remember that the engine of the tested car featured different torque curves for gasoline fuelling and CNG fuelling, which is why a significant difference in the dynamics of acceleration for those two fuels occurs.

In the next Fig. 7 and 8 variability of accelerations have been shown: real and substitute one, in the function of covered distance for gasoline and $\mathrm{CNG}$ fuelling.

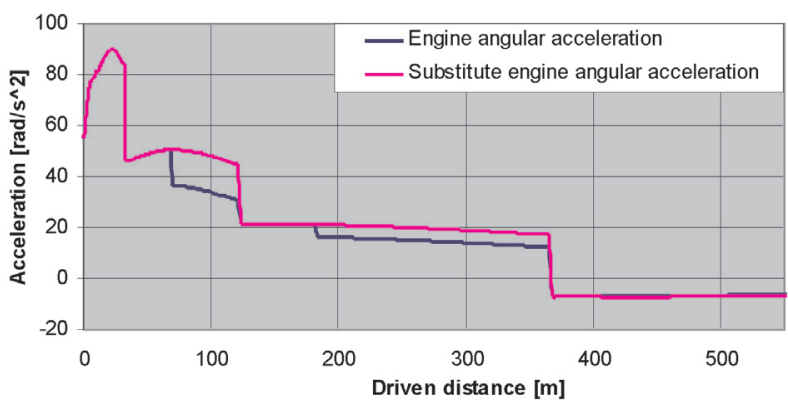

Fig. 7. Variability of acceleration in the function of covered distance for gasoline fuelling

Rys. 7. Zmienność przyspieszenia jako funkcja drogi dla zasilania benzyna

Comparing the diagrams shown in Fig. 7 and 8, one can notice significantly lower accelerations obtained in the case of CNG fuelling, which effected in longer times necessary to cover the assumed distance during individual phases of the test.

In Fig. 9 the courses of transient fuel consumption during the individual phases of the test for gasoline and $\mathrm{CNG}$ fuelling.

The emissions of exhaust gas components emitted during individual phases of the test should be considered as very important information. Such information can be obtained from the dynamic characteristics shown in Fig. 3 and 4. Similar data can be obtained for other exhaust gas components such as $\mathrm{CO}, \mathrm{HC}$ and $\mathrm{NO}_{\mathrm{x}}$, whose characteristics were elaborated similarly to those of $\mathrm{CO}_{2}$, but due to a limitation in size of the present paper have not been included. In Fig. 10 the emissions of $\mathrm{CO}_{2}$ for gasoline and $\mathrm{CNG}$ fuelling for individual phases of the test have been shown.
Table 1. Course of the accomplished driving test for CNG fuelling

Zżenia do porównawczego, dynamicznego testu jezdnego przy zasilaniu CNG

\begin{tabular}{|l|c|c|c|c|c|c|}
\hline Phase/faza & I & II & III & IV & V & VI \\
\hline Gear/bieg & I & II & II & III & III & III \\
\hline Climbing angle $\alpha[\mathrm{deg}] /$ kąt & 0 & 0 & 3 & 0 & 1,5 & 0 \\
\hline $\begin{array}{l}\text { Maximum engine speed } \\
{[\mathrm{rad} / \mathrm{s}] / \text { maksymalna prędkośc }} \\
\text { obrotowa silnika [rad/s] }\end{array}$ & 500 & 400 & 500 & 400 & 500 & calcul. \\
\hline $\begin{array}{l}\text { Covered distance }[\mathrm{m}] / \text { przebyty } \\
\text { dystans [m] }\end{array}$ & 32.41 & 68.03 & 121.21 & 181.09 & 365.97 & 531.31 \\
\hline
\end{tabular}

\section{Uzyskane wyniki}

Oceniając uzyskane wyniki, należy pamiętać, że silnik badanego samochodu miał odmienne charakterystyki szybkościowe przy zasilaniu benzyną i gazem CNG, stąd znacząca różnica $\mathrm{w}$ dynamice rozpędzania dla tych dwóch paliw.

Na rysunkach 7 i 8 przedstawiono zmienność przyspieszenia: rzeczywistego i zastępczego (wzór 8) w funkcji drogi dla zasilania benzyną i CNG.

Porównując wykresy zamieszczone na rys. 7 i 8, można zauważyć znacząco mniejsze przyspieszenia osiągane przy

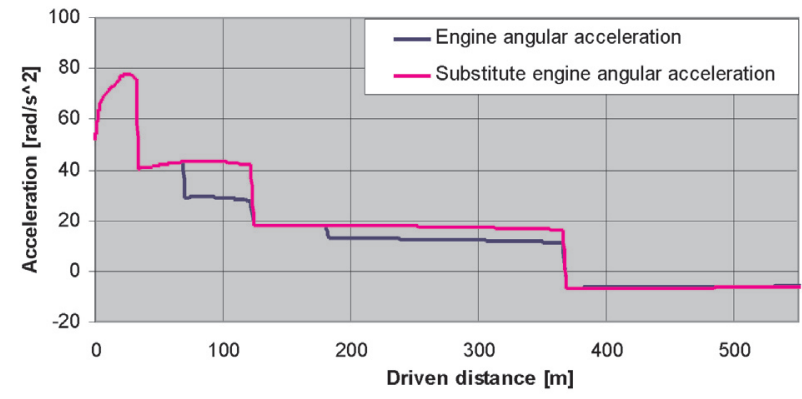

Fig. 8. Variability of acceleration in the function of covered distance for CNG fuelling

Rys. 8. Zmienność przyspieszenia jako funkcja drogi dla zasilania CNG

zasilaniu CNG, co skutkowało dłuższym czasem potrzebnym do osiągnięcia założonej drogi w poszczególnych fazach testu.

$\mathrm{Na}$ rysunku 9 uwidoczniono przebiegi chwilowego zużycia paliwa przy realizacji poszczególnych faz testu dla zasilania benzyną i CNG.

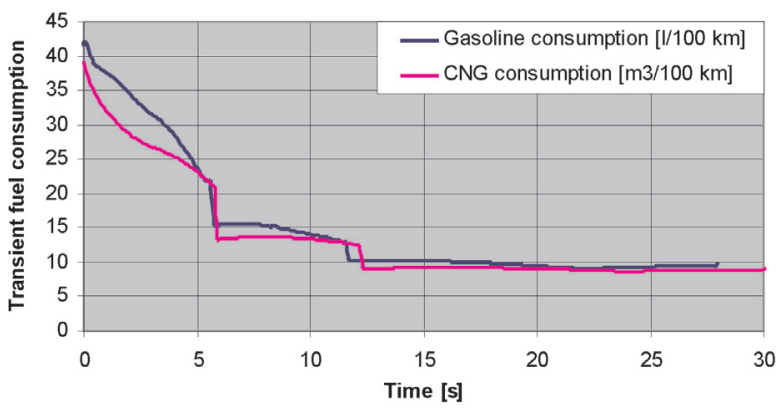

Fig. 9. Courses of transient gasoline and $\mathrm{CNG}$ consumption in the function of time

Rys. 9. Przebiegi chwilowego zużycia benzyny (w dm $\left.\mathrm{dm}^{3} / 100 \mathrm{~km}\right)$ i gazu CNG $\left(\mathrm{w} \mathrm{m}^{3} / 100 \mathrm{~km}\right)$ jako funkcja czasu 


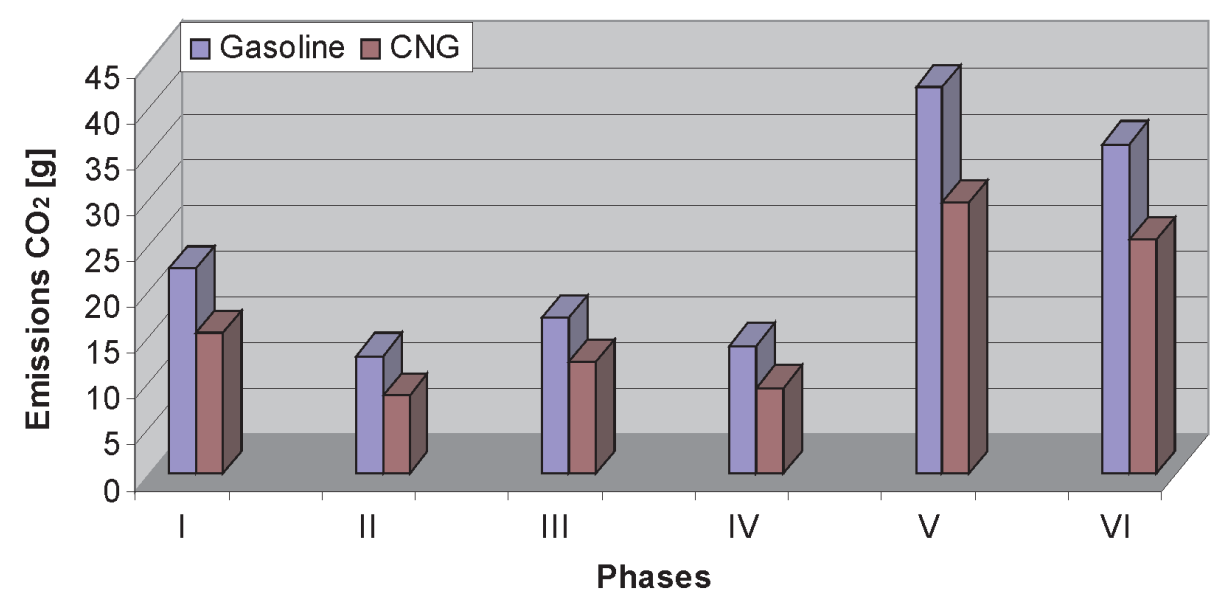

Fig. 10. $\mathrm{CO}_{2}$ emissions for gasoline and $\mathrm{CNG}$ fuelling during individual phases of the test Rys. 10. Emisja $\mathrm{CO}_{2}$ dla zasilania benzyna i gazem $\mathrm{CNG}$ w poszczególnych fazach testu

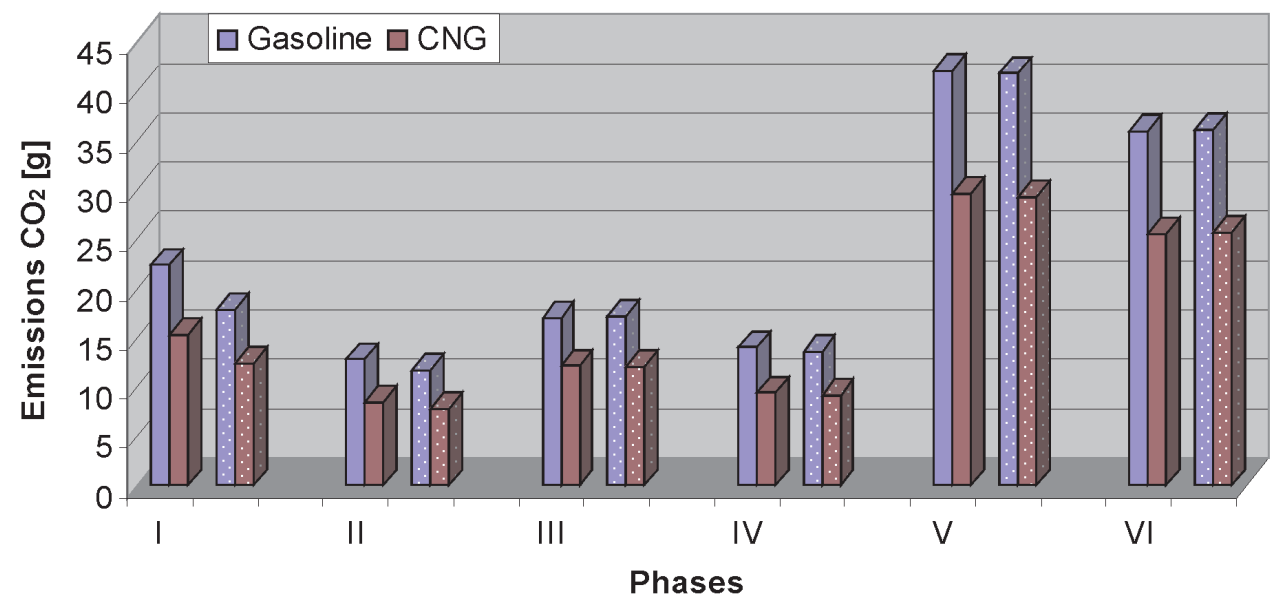

Fig. 11. $\mathrm{CO}_{2}$ emissions during individual phases of the test. Dotted columns concern the case where accelerations were not taken into account

Rys. 11. Emisja $\mathrm{CO}_{2}$ w poszczególnych fazach testu; kolumny kropkowane dotycza braku uwzględniania przyspieszeń

The determining of the significance of the acceleration taken into account for the calculated data is another interesting issue analyzable with the use of the developed dynamic characteristics. suitable computer simulations have been performed, where in one case only the speed profile of the prescribed test was taken into account, in the second case the full dynamic characteristics has been used (the data calculated in the function of speed and acceleration). Example results have been shown in the successive figures.

\section{Summary}

In the present paper the authors have proved that:

1. The developed dynamic characteristic can reflect all four main motion resistances and can serve as an effective tool for qualitative and quantitative analysis of fuel consumption and exhaust gas emissions for the assumed scenario of motion.
Za bardzo istotną należy uznać emisję składników spalin wydzielanych w poszczególnych fazach testu. Dane te można uzyskać z charakterystyk dynamicznych przedstawionych na rys. 3 i 4. Podobne dane można uzyskać dla innych składników spalin, takich jak $\mathrm{CO}, \mathrm{HC}$ i $\mathrm{NO}_{x}$, których charakterystyki opracowano podobnie jak dla $\mathrm{CO}_{2}$, lecz nie zamieszczono w niniejszej publikacji. Na rysunku 10 przedstawiono emisję $\mathrm{CO}_{2}$ przy zasilaniu benzyną i gazem CNG dla poszczególnych faz testu.

Ciekawym zagadnieniem do analizy za pomocą opracowanych charakterystyk dynamicznych jest określenie istotności uwzględniania przyspieszenia do obliczanych danych. Przeprowadzono symulacje komputerowe emisji związków toksycznych, w których w jednym przypadku uwzględniano jedynie profil prędkości zadanego testu, a w drugim - posługiwano się pełnymi charakterystykami dynamicznymi (obliczano dane jako funkcje prędkości i przyspieszeń pojazdu). Na rysunkach 11 i 12 zestawiono przykładowe wyniki.

\section{Podsumowanie}

W niniejszej publikacji wykazano, że:

1. Opracowane charakterystyki dynamiczne mogą odzwierciedlać wszystkie cztery główne opory ruchu i być skutecznym narzędziem do analiz ilościowych i jakościowych zużycia paliwa i emisji składników spalin dla założonego scenariusza ruchu.

2. Uzyskano potwierdzenie korzyści ekologicznych [8] ze stosowania gazu CNG do napędu samochodu w postaci obniżonej emisji $\mathrm{CO}_{2}$ w stosunku do zasilania benzyną dla wszystkich faz testu.

3. Można się spodziewać, że przy napędzie gazem CNG jako głównym paliwem (przy odpowiednim przygotowaniu 
2. The authors have confirmed the ecological benefits of CNG fuelling [8] in all the phases of the test (a reduced $\mathrm{CO}_{2}$ emissions compared to gasoline).

3. It can be expected, that with $\mathrm{CNG}$ as the main fuel (after suitable engine modification) the dynamics of acceleration should be comparable with a car fuelled with gasoline and the ecological benefits shall remain on a similar level.

4. The methodology pre-

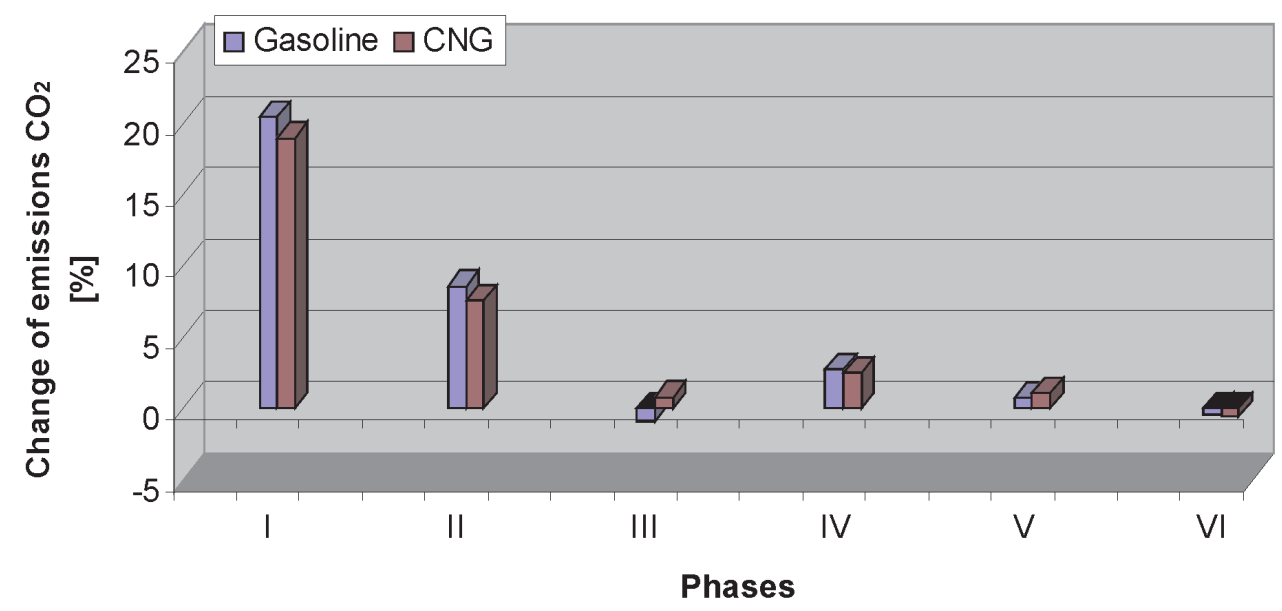

Fig. 12. The change of the calculated $\mathrm{CO}_{2}$ emissions including and excluding the acceleration Rys. 12. Zmiana wyznaczonej emisji $\mathrm{CO}_{2}$ przy uwzględnieniu i bez uwzględniania przyspieszenia sented in the present paper can also be useful to analyze vehicle motion in various configurations of terrain and various assumed scenarios of traffic.

5. The calculations of exhaust gas emissions and fuel consumption based exclusively on the speed profile can lead to a significant error.

Artykut recenzowany

silnika) dynamika rozpędzania nie będzie gorsza jak przy zasilaniu benzyną, a korzyści ekologiczne pozostaną na podobnym poziomie.

4.Przedstawiona $\mathrm{w}$ artykule metodyka postępowania może być przydatna do analiz ruchu pojazdów przy różnym ukształtowaniu terenu i różnych scenariuszach ruchu.

5. Opieranie obliczeń emisji składników spalin i zużycia paliwa jedynie na profilu prędkości prowadzi do istotnych błędów.

\section{Bibligraphy/Literatura}

[1] Brzozowski K., Romaniszyn K.M.: An effective method creating dynamic characteristics using drive tests. The Archive of Mechanical Engineering 4/2003, vol. L, s. 391-408.

[2] Nowak A., Romaniszyn K.M.: Charakterystyki emisji zanieczyszczeń z samochodowych silników spalinowych w warunkach dynamicznych. Inżynieria Maszyn, vol. 8, z. 4, 2003.

[3] Romaniszyn K. M.: Ocena błędów wynikających z posługiwania się aproksymowanymi charakterystykami dynamicznymi. Zeszyt Naukowy OBR BOSMAL nr 29 (III) 2005, s.15-25.

[4] Romaniszyn K.M.: Właściwości dynamiczne i emisyjność składników spalin samochodów zasilanych alternatywnie benzyną i gazami LPG i CNG. WNT, Warszawa 2007.

[5] Romaniszyn K.M.: Dynamika rozpędzania samochodu zasilanego benzyną i gazem CNG. Silniki Spalinowe 2/2006 (125), s. $67-73$

Mr. Kazimierz Romaniszyn, DSc, DEng. - professor in the Departament of Internal Combustion Engines and Vehicles at Technical University of Bielsko-Biała.

Dr hab. inż. Kazimierz Romaniszyn - profesor nadzwyczajny w Katedrze Silników i Pojazdów Akademii Techniczno-Humanistycznej w Bielsku-Białej.

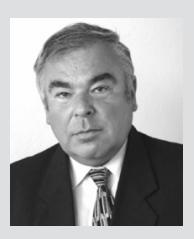

[6] Romaniszyn K.M.: Ocena błędów wynikających z posługiwania się aproksymowanymi charakterystykami dynamicznymi. Zeszyt Naukowy OBR BOSMAL nr 29 (III) 2005, s.15-25.

[7] Kończykowski W.: Odtwarzanie i analiza wypadku drogowego. SRTSiRD, Warszawa-Paryż 1993.

[8] Merkisz J., Pielecha I.: Alternatywne paliwa i układy napędowe pojazdów. Wydawnictwo Politechniki Poznańskiej, Poznań 2004.

[9] Prochowski L.: Mechanika Ruchu. Seria Pojazdy Samochodowe, WKiŁ, Warszawa 2005.

Mr. Krzysztof Parczewski, DEng. - doctor in the Departament of Internal Combustion Engines and Vehicles at Technical University of Bielsko-Biała.

Dr inż. Krzysztof Parczewski - adiunkt w Katedrze Silników Spalinowych i Pojazdów Akademii Techniczno-Humanistycznej w Bielsku-Białej.

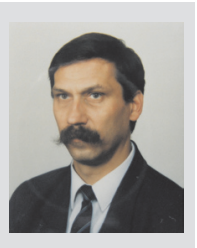

Mr. Henryk Wnęk, DEng. - doctor in the Departament of Internal Combustion Engines and Vehicles at Technical University of Bielsko-Biała.

Dr inż. Henryk Wnęk-adiunkt w Katedrze Silników Spalinowych i Pojazdów Akademii Techniczno-Humanistycznej w Bielsku-Białej. 